\title{
Assessing groundwater vulnerability to pollution in the Puck region (denudation moraine upland) using vertical seepage method
}

\author{
Dawid Potrykus ${ }^{1, *}$, Anna Gumuła-Kawęcka ${ }^{1}$, Beata Jaworska-Szulc ${ }^{1}$, Małgorzata \\ Pruszkowska-Caceres ${ }^{1}$, and Adam Szymkiewicz ${ }^{1}$ \\ ${ }^{1}$ Gdańsk University of Technology, Faculty of Civil and Environmental Engineering, 80-233 Gdańsk, \\ ul. Narutowicza $11 / 12$, Poland
}

\begin{abstract}
Degradation of groundwater quality can cause a serious water supply and environmental problems. The identify of potential groundwater pollution can be determined by assessment of groundwater vulnerability method. The assessment of groundwater vulnerability to pollution was based on estimation of migration time of potential conservative contamination through the vadose zone. Area of investigation is a type of denudation moraine upland, which is situated at the eastern part of the Puck Isolated Morainic Plateau (north of Poland). Time of vertical seepage was estimated with four widely use in Poland equations and numerical modelling with HYDRUS 1D numerical code. The results were compared with major groundwater basin (MGWB) vulnerability classification. The calculations indicate variable results of migration times for conservative contamination, depending on the chosen equation. The conducted research is a part of a project which main aim is a development of groundwater contaminant transport model and detailed identification of a potential agriculture pollutant sources in the selected watersheds of the Puck Bay.
\end{abstract}

\section{Introduction}

One of the biggest threats and challenging problem for human population and economy is pollution of groundwater. It is generally related to the degradation of groundwater quality, which can cause a serious water supply and environmental problems. Groundwater pollution is mainly a results of inappropriate land management practices and human activity, especially in areas of beneficial recharge conditions. The foundations of groundwater vulnerability to pollution should be a detailed recognition of the hydrogeological conditions. International Association of Hydrogeologists (IAH) define vulnerability as an intrinsic property of a groundwater system that depends on the sensitivity of that system to human and/or natural impacts [1]. There is number of methods to estimation of potential pollutant migration into groundwater [1-5]. Assessment of groundwater vulnerability can be determined by identifying time of conservative contaminant as save approach.

\footnotetext{
*Corresponding author: dawpotry@pg.edu.pl
} 
The presented study is an initial assessment of groundwater vulnerability to pollution in the Puck region, situated at the north of Poland, at the west coast of Bay of Puck. The seaside location and unique environmental values cause main sources of local inhabitants incomes come from agriculture, fishery and tourism. All these activities are groundwaterdependent in various degree and potential degradation of groundwater quality have significant influence on the analysed region.

\section{Area of study}

Study area is located in the Kashubian Coastland mesoregion with a significant differences in a terrain. Kashubian Coastland is a type of young glacial landscape which constitutes a network of isolated morainic plateau patches separated by ice marginal valleys. Topography of this region is a result of various sedimentation factors and processes during the Quaternary [6]. Area of investigation is a type of denudation moraine upland, which is situated at the eastern part of the Puck Isolated Morainic Plateau (Puck Morainic Upland) (Fig.1).

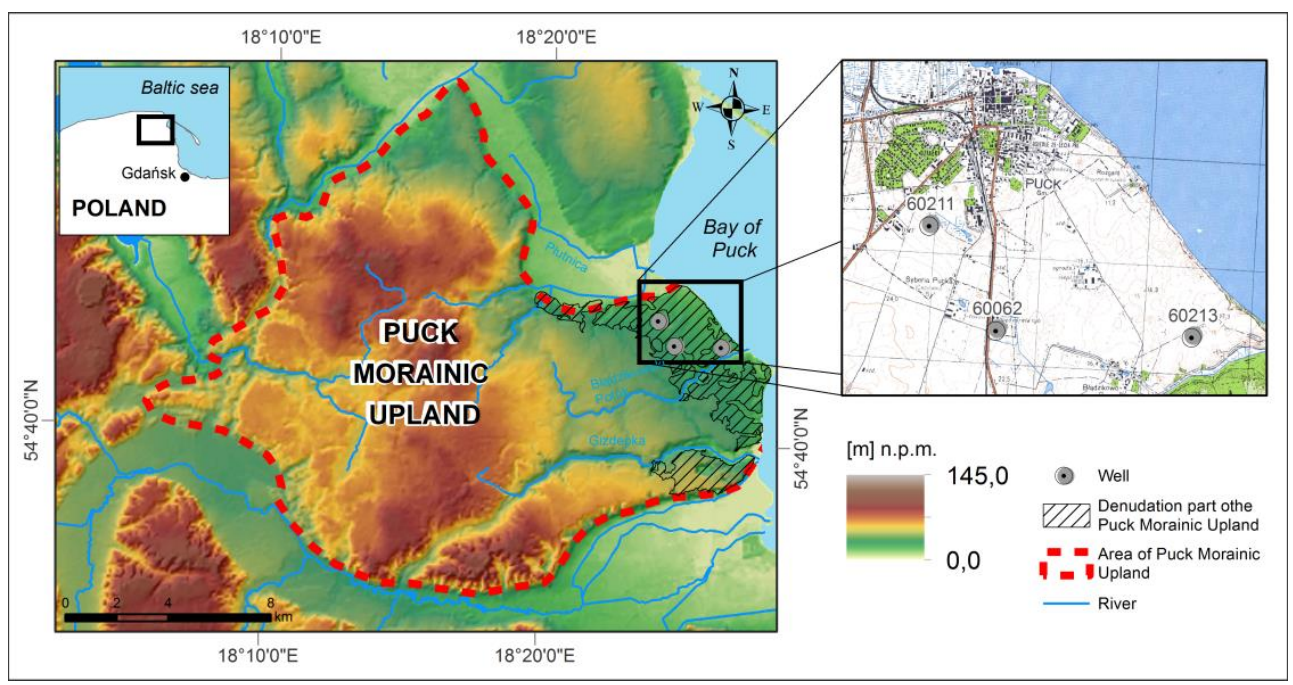

Fig.1. Research area.

The Puck Isolated Morainic Plateau is one of the largest isolated morainic plateau of the Kashubian Coastland, covering an area of $255 \mathrm{~km}^{2}$. The landscape of this specific upland area is diversified with valley cuts, of which the two largest ones are now used by Gizdepka and Błądzikowski Potok rivers. The main part of the Puck Isolated Morainic Plateau consist of till deposits, which are divided by series of fluvioglacial sands and gravels. Till deposits of the last glaciation, laying on the surface are locally covered with fluvioglacial or silty sands. The bottoms of river valleys are covered with peaty sands. The thickness of the Quaternary sediments ranges from $40 \mathrm{~m}$ in the eastern part to $95-100 \mathrm{~m}$ in the western part [7].

The vicinity of Baltic sea creates a specific marine climate in this region, which is characterized by moderate winters and mild summers. The annual temperature is around $7.4^{\circ} \mathrm{C}$ and the average amount precipitation does not exceed $700 \mathrm{~mm}$ [8]. Meteorological data were obtained from the weather station operated by the Department of Hydraulic Engineering, Gdańsk University of Technology. 
The Kashubian Coastland is an instance of a hydrogeological diversified region where various groundwater occurrence is observed. On the Puck Isolated Morainic Plateau hydrogeology conditions are mostly dependent on terrain variability and geological setting. Due to the aim of the research, the investigation focused on the first aquifer below the ground surface.

Locally, groundwater occurs in subsurface sands (type of perched aquifer) and in the form of sand lenses enclosed in till deposits. These aquifers are situated at depths up to 5-10 $\mathrm{m}$ below the surface. Shallow aquifers in the Puck Isolated Morainic Plateau do not play an important role in water supply, but they are still exploited in some villages mainly for farm and cottage houses needs. Only deeper aquifers $(20-50 \mathrm{~m}$ b.g.l) can be classified as useful for water supplies [9]. In Puck Isolated Morainic Plateau region, two aquifers are adequate for water supplies have been identified: sub-till aquifer (first) and inter-till aquifer (second) [8]. The aquifers material is series of fluvioglacial sediments (sands and gravels) which separate till deposits. Both aquifers are hydraulically connected and confined, except areas where till cover was eroded, sub-till aquifer is uncovered thus it is unconfined. Hydrosystem is drained mainly by the Baltic Sea, however locally river valleys and ice marginal valleys also play a significant role. In the Bay of Puck coastline, few natural groundwater outflows are also observed.

Potential sources of groundwater pollution in the study area is related to agricultural land use, which requires usage of fertilizers and pesticides. Shallow water table, vadose zone consist of low permeable material and flat topography in area of investigation create good conditions of potential pollutant infiltration.

Shallow aquifer in the area of analysed wells is unconfined. The water table is situated at 5.0 meters above sea level and it is decreasing in the Bay of Puck direction. Thickness of the vadose zone (basis on the analysed profiles - Fig.2) is in range 8-16 meters. Vadose zone is consist of low permeable materials in such as moraine till and sandy clay. Permeable clay sands, sands and locally gravels lay below.

\section{Methodology and materials}

The assessment of groundwater vulnerability to pollution was based on estimation of time which potential conservative contamination needs to reach the aquifer from the ground level. Considering infiltration time as groundwater vulnerability indicator it is a significant criterion for estimating risk of groundwater quality degradation. Identifying of migration time base on the determination of average velocity of vertical water seepage, assuming piston-flow model [10]. This approach assumes that potential contamination will appear in the aquifer later than infiltrating water what allows to plan necessary activities for water protection. Time of vertical seepage was estimated with four equations (eq. 1-7) and numerical modelling with HYDRUS 1D numerical code [11]. The results were compared with major groundwater basin (MGWB) classification (Table 1) [12].

Table 1. Applied classification of groundwater vulnerability [12].

\begin{tabular}{|c|c|c|c|c|c|}
\hline $\begin{array}{c}\text { Time of vertical } \\
\text { seepage [years] }\end{array}$ & $<\mathbf{2}$ & $\mathbf{2 - 5}$ & $\mathbf{5 - 2 5}$ & $\mathbf{2 5 - 1 0 0}$ & $>\mathbf{1 0 0}$ \\
\hline $\begin{array}{c}\text { Class of } \\
\text { groundwater } \\
\text { vulnerability }\end{array}$ & $\begin{array}{c}\text { extremely } \\
\text { vulnerable }\end{array}$ & $\begin{array}{c}\text { highly } \\
\text { vulnerable }\end{array}$ & $\begin{array}{c}\text { moderately } \\
\text { vulnerable }\end{array}$ & $\begin{array}{c}\text { low } \\
\text { vulnerable }\end{array}$ & $\begin{array}{c}\text { very low } \\
\text { vulnerable }\end{array}$ \\
\hline
\end{tabular}

The investigation was carried out for three representative profiles (marked on the Fig.1). All of them are situated at agriculture area. The hydrogeological data have been obtained from the HYDRO Bank, archival documentations and other studies [12-15]. 


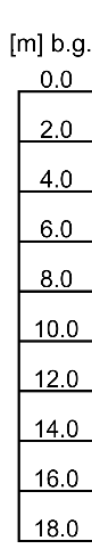

60062

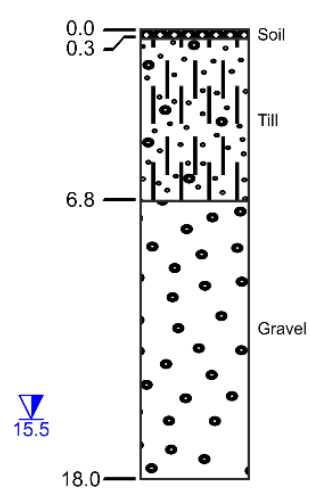

60211

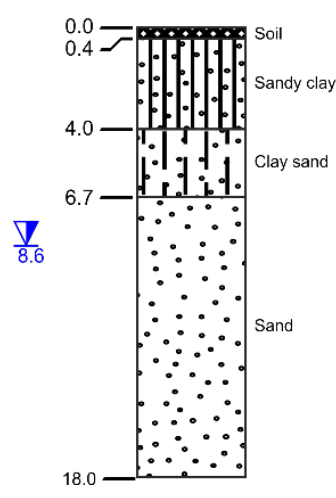

60213

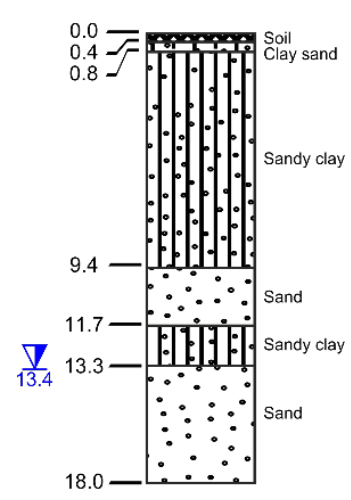

Fig.2. Hydrogeological profiles.

\subsection{Vertical seepage time equations}

The most widely used criteria of groundwater vulnerability classification in Poland are time of vertical seepage equations $[3,5,10,12-14,16,17]$. Detailed analyses of equations application were elaborated by Rodzoch [16], Macioszczyk [10] and Liszkowska [17]. Time of contaminant transport through the vadose zone was calculated with the application of the following equations:

Equation 1 - Bachmat and Collin's formula [18]:

$$
t_{a}=\sum_{i=1}^{n} \frac{m_{i} \cdot\left(w_{o}\right)_{i}}{I_{e}}
$$

Equation 2 - Bindeman's formula [12]:

$$
t_{a}=\sum_{i=1}^{n} \frac{m_{i} \cdot n_{e}}{\sqrt[3]{I_{e}^{2} \cdot k^{\prime}}}
$$

Equation 3 - Bindeman's formula modified by Macioszczyk [10]:

$$
t_{a}=\sum_{i=1}^{n} \frac{m_{i} \cdot\left(w_{o}\right)_{i}}{\sqrt[3]{I_{e}^{2} \cdot k^{\prime}}}
$$

Denotations for above equations $(1,2,3)$ :

$t_{a}$ - time of vertical seepage through the unsaturated zone [d],

$m_{i}$ - thickness of successive layers of unsaturated zone profile [m],

$w_{O} \quad$ - average volumetric content of successive layers of unsaturated zone [-],

$n_{e} \quad$ effective porosity [-],

$k^{\prime} \quad$ - vertical hydraulic conductivity of unsaturated zone $[\mathrm{m} / \mathrm{d}]$,

$I_{e} \quad$ - infiltration of precipitation deep into the soil profile $\left(I_{e}=P \cdot w\right)[\mathrm{m} / \mathrm{d}]$,

$P \quad$ - amount of precipitation [mm/a],

$w \quad-$ infiltration rate [-]. 
Equation 4 - MRT algorithm, introduced for needs of groundwater vulnerability mapping in Poland [5]:

$$
\begin{aligned}
& M R T=M R T_{s}+M R T_{1}+M R T_{2} \\
& M R T_{s}=\frac{m_{g} \cdot w_{o g}}{I_{e}} \\
& M R T_{1}=\frac{\left(m_{a}-m_{g}\right) \cdot(1-S p) \cdot w_{o p}}{I_{e}} \\
& M R T_{2}=\frac{\left(m_{a}-m_{g}\right) \cdot S p \cdot w_{o i}}{I_{e}}
\end{aligned}
$$

Denotations for above MRT algorithm (4, 5, 6, 7):

$M R T$ - total time of water exchange due to infiltration [d], $M R T_{s}$ - water exchange time in soil profile $\left(M R T_{s}\right)[\mathrm{d}]$, $M R T_{1}$ - water exchange time in unsaturated zone of permeable rocks [d], $M R T_{2}$ - water exchange time in low permeable and confining rocks in unsaturated zone profile [d], $m_{a}$ - thickness of unsaturated zone profile [m], $m_{g}$ - thickness of soil profile [m], $w_{o g}$ - volumetric water content in soil profile [-],

$w_{o p}$ - volumetric water content in main lithotypes of the aquifer permeable cover [-], $w_{o i}$ - volumetric water content in main lithotypes of the aquifer low permeable cover [-], $S p$ - ratio of low permeable rocks in the aquifer cover [-], $I_{e}$ - infiltration of atmospheric precipitation deep into the soil profile (methodology in [5]) $[\mathrm{m} / \mathrm{d}]$.

\subsection{Numerical modelling}

Three, one dimensional, numerical models of vadose zone were developed, representing profiles of boreholes (Fig. 1-2). The profiles vary with soil material and depth of water table. The calculations were processed with HYDRUS-1D which simulates the transient movement of water, solute, and heat in variably-saturated soil. The software using finite element discretization in space to solve the Richards Equation and fully implicit discretization in time.

The simulations were performed as a theoretical experiment to investigate influence of geology on vertical seepage time. Therefore geological and hydrogeological parameters of the models, such as hydraulic conductivity and water content in residual soil and in saturation state was assigned as representative values based on [15] (Table 2). Hydraulic characteristic of each type of soil was determined with van Genuchten-Mualem function [19]. The weather data such as annual temperature, air humidity observations and annual amount of precipitation was obtained from meteorological station in Gdańsk. Potential evapotranspiration was estimated with Grabarczyk formula [20] and distributed proportionally through a root zone with maximal values assigned at the top of the model, and minimal values at the bottom. To simulate vegetative cover (wheat) parameters of root water uptake was set according to Wessling [21] with thickness of root zone equals to $1 \mathrm{~m}$. The simulations were carried out for the years 2011-2015 with daily time step. Each model was discretized vertically with nodes placed with intervals of $10 \mathrm{~cm}$. Upper boundary 
condition reflect free surface runoff while lower boundary condition was assigned as constant pressure head (water table level).

The pollution was assigned as a constant injection of contaminant solved in infiltrating water. Migration of conservative solute was simulated based on advective-dispersive transport equation. The Galerkin Finite Elements method was applied to solve spatial derivatives of the formula. The time of the simulation was discretized with Crank-Nicholson implicit scheme.

Table 2. Parameters of the van Genuchten-Mualem hydraulic model for the soils assigned in simulations.

\begin{tabular}{|c|c|c|c|c|c|}
\hline Type of soil & $\begin{array}{c}\text { Residual } \\
\text { water content } \\
\boldsymbol{\theta}_{\mathbf{r}}\end{array}$ & $\begin{array}{c}\text { Saturated soil } \\
\text { water content } \\
\boldsymbol{\theta}_{\mathbf{s}}\end{array}$ & $\begin{array}{c}\text { Parameter } \boldsymbol{\alpha} \\
\text { of soil water } \\
\text { retention } \\
\text { function } \\
{[\mathbf{1} / \mathbf{m m}]}\end{array}$ & $\begin{array}{c}\text { Parameter } \\
\boldsymbol{n} \text { of soil water } \\
\text { retention } \\
\text { function }\end{array}$ & $\begin{array}{c}\text { Hydraulic } \\
\text { conductivity } \\
\mathbf{K} \text { s } \\
\text { [cm/d] }\end{array}$ \\
\hline $\begin{array}{c}\text { Sand and } \\
\text { Gravel }\end{array}$ & 0.045 & 0.43 & 0.145 & 2.68 & $712.8-1000.0$ \\
\hline Clay sand & 0.057 & 0.41 & 0.124 & 2.28 & 350.2 \\
\hline Sandy clay & 0.065 & 0.41 & 0.075 & 1.89 & 106.1 \\
\hline Till & 0.078 & 0.43 & 0.036 & 1.56 & 24.96 \\
\hline
\end{tabular}

\section{Results and discussion}

Results obtained from different methods are compared in Table 3. Determination of Bachmat and Collin's equation (1) and MRT formula (4) indicate an astonishingly long time of infiltration, respectively 9653 to 15261 days and 8415 to 15200 days (Table 3). Equation 1 states that infiltration through the unsaturated zone primarily depends on volumetric content of sediments due to recharge by infiltration. MRT algorithm basis on the Bachmat and Collin's formula, but also consider exchange time of volumetric water content of soil and sediment vadose zone's.

The other methods give lower values and seem to be more appropriate for this case. Migration time calculated with Bindeman's equation (2) ranges from 257 to 699 days (Table 3). This method takes into account effective porosity and hydraulic conductivity of the unsaturated zone, but it is neglecting a role of effective infiltration. Modified Bindeman's equation, proposed by Macioszczyk (3), considers volumetric content of the unsaturated zone instead of effective porosity. Time of vertical flow, determined by this formula is from 445 to 945 days.

Calculations performed on the basis of previous studies in hydrogeological practice [3, $5,10,16,17]$, the dependence of the parameters applied in formulas to the permeability characteristics of vadose zone is noticeable. An unexpectedly high impact of groundwater protection is assign to sediments by using Bachmat and Collin's equation and MRT algorithm. On the other hand, using the Bindeman equation, lower values of vertical seepage time have been always obtained. Differences in calculations are systematic and repetitive for these equations $[10,16]$. Consider volumetric content of unsaturated zone instead of effective porosity seems to be proper for infiltration through the vadose zone. Effective porosity determines the potential maximum of the soil to conduct the water, assuming constant intensity of infiltration, which in natural conditions of unsaturated zone is never reflected [17]. 
Table 3. Time of vertical seepage through the unsaturated zone.

\begin{tabular}{|c|c|c|c|c|c|}
\hline $\begin{array}{c}\text { Well } \\
\text { number }\end{array}$ & $\begin{array}{c}\text { Bachmat and } \\
\text { Collin's } \\
\text { equation (1) }\end{array}$ & $\begin{array}{c}\text { Bindeman's } \\
\text { equation (2) }\end{array}$ & $\begin{array}{c}\text { Macioszczyk's } \\
\text { equation (3) }\end{array}$ & $\begin{array}{c}\text { MRT } \\
\text { algorithm } \\
(\mathbf{4}-\mathbf{7})\end{array}$ & Hydrus 1D \\
\cline { 2 - 6 } & \multicolumn{5}{|c|}{ [time] } \\
\hline 60062 & $\begin{array}{c}13240 \text { days } \\
(\sim 36.3 \text { years })\end{array}$ & $\begin{array}{c}699 \text { days } \\
(\sim 1.9 \text { years })\end{array}$ & $\begin{array}{c}945 \text { days } \\
(\sim 2.6 \text { years })\end{array}$ & $\begin{array}{c}12828 \text { days } \\
(\sim 35.2 \text { years })\end{array}$ & $\begin{array}{c}989 \text { days } \\
(\sim 2.7 \text { years })\end{array}$ \\
\hline 60211 & $\begin{array}{c}9653 \text { days } \\
(\sim 26.4 \text { years })\end{array}$ & $\begin{array}{c}257 \text { days } \\
(\sim 0.7 \text { years })\end{array}$ & $\begin{array}{c}445 \text { days } \\
(\sim 1.2 \text { years })\end{array}$ & $\begin{array}{c}8415 \text { days } \\
(\sim 23.1 \text { years })\end{array}$ & $\begin{array}{c}446 \text { days } \\
(\sim 1.2 \text { years })\end{array}$ \\
\hline 60213 & $\begin{array}{c}15261 \text { days } \\
(\sim 41.8 \text { years })\end{array}$ & $\begin{array}{c}372 \text { days } \\
(\sim 1.0 \text { years })\end{array}$ & $\begin{array}{c}802 \text { days } \\
(\sim 2.2 \text { years })\end{array}$ & $\begin{array}{c}15200 \text { days } \\
(\sim 41.6 \text { years })\end{array}$ & $\begin{array}{c}861 \text { days } \\
(\sim 2.4 \text { years })\end{array}$ \\
\hline
\end{tabular}

\section{Summary and conclusions}

The groundwater vulnerability assessment in denudation part of the Puck Isolated Morainic Plateau was determined using the time of the vertical seepage method as a significant factor. The calculations indicate variable results of migration times for conservative contamination, even by few orders of magnitude, depending on the chosen equation. However, one quite obvious regularity was observed. The migration time is the longer the thicker interbedding till layer was in the profile. Differences between calculated values are result of the hydrogeological parameters adopted in formulas. The problem of discrepancies between these equations is widely discussed in the literature [10, 13, 17], however, the results obtained from the model show the greatest convergence with the Macioszczyk equation (3).

Rationally assessment of groundwater vulnerability is difficult. Time of vertical seepage, determined by Bachmat and Collin's equation (1) and MRT algorithm (4) classify investigated area to low class of vulnerability (25-50 years). Basis on the Bindeman's equation results, area under study is classified as extremely vulnerable ( $<2$ years). Results obtained by model and Macioszczyk equation (3) classify investigated area to highly vulnerable (2-5 years) (well no. 60062 and 60213) and extremely vulnerable ( $<2$ years) (well no. 60211).

To determine the reliability of groundwater vulnerability to pollution, the calculations should be confirmed by in-situ tests.

This work has been supported by National Centre for Research and Development, Poland, in the framework of the project BIOSTRATEG3/343927/3/NCBR/2017 "Modelling of the impact of the agricultural holdings and land-use structure on the quality of inland and coastal waters of the Baltic Sea set up on the example of the Municipality of Puck region - Integrated info-prediction Web Service WaterPUCK" - BIOSTRATEG Programme.

\section{References}

1. J. Vrba, A. Zaporozec (eds.), Guidebook on mapping groundwater vulnerability (IAH, 16, 1994)

2. R. Kaur, K.G. Rosin, Division of Environmental Sciences - Indian Agricultural Research Institute (2007)

3. E. Krogulec, IAH Selected Papers 11,125 (2004)

4. E. Krogulec, Earth Sci. \& Clim. Change 4, 159 (2013) 
5. R. Duda, S. Witczak, A. Żurek, Map of groundwater vulnerability to pollution in Poland, a scale of 1:500,000-methodology and text explanations (2011)

6. R.J. Sokołowski (ed.), Ewolucja środowisk sedymentacyjnych regionu Pobrzeża Kaszubskiego (2014)

7. K. Jereczek-Korzeniowska, W. Jegliński, Geologia 53, 10 (2011)

8. E. Frączek, Hydrogeological map of Poland 1:50 000 (Puck, PIG, 1998)

9. P. Nerkowski Hydrogeological map of Poland - first aquifer 1:50 000 (Puck, PGI, (2010)

10. T. Macioszczyk, Przegl. Geol. 47, 731 (1999)

11. J. Šimůnek, M. van Genuchten, M. Šejna, Vadose Zone J. 7, 2, 587 (2008)

12. A.S. Kleczkowski (ed.) The map of the Critical Protection Areas (CPA) of the Major Groundwater Basins (MGWB) in Poland 1:500 000 (1990)

13. R. Duda, B. Winid, R. Zdechlik, M. Stępień, Metodyka wyboru optymalnej metody wyznaczania zasięgu stref ochronnych ujęć zwyktych wód podziemnych w uwzględnieniem warunków hydrogeologicznych obszaru RZGW w Krakowie (2013)

14. S. Witczak, A. Żurek, Metodyczne podstawy ochrony wód podziemnych (A.S. Kleczkowski ed.), 155-180 (1994)

15. R.F. Carsel, R.S. Parrish, Water Resour. Res. 24, 755 (1988)

16. A. Rodzoch, WPH Conf. Papers 8, 183-188 (1997)

17. E. Liszkowska, Przegl. Geol. 65, 1109 (2017)

18. A.S. Kleczkowski (ed.) Ochrona wód podziemnych (Wyd. Geol., 1984)

19. M.Th. van Genuchten, Soil Sci. Soc. Am. J. 44, 892 (1980)

20. S. Grabarczyk, J. Żarski, Zeszyty Problemowe Postępów Nauk Rolniczych 327, 161 (1986)

21. J.G. Wesseling, J.A. Elbers, P. Kabat, B.J. van den Broek, SWATRE: instructions for input, Internal Note (Winand Staring Centre, 1991) 